\title{
Kształtowanie się ubóstwa jako wynik współczesnych procesów globalizacyjnych
}

Globalizacja - według Stownika zarzqdzania i finansów (Koch 1997, s. 76) - oznacza: „proces upodabniania się gustów i oferty produktu na całym świecie, wskutek czego popyt jest zaspokajany produktem globalnym, a nie lokalnymi”. Globalizacja jest realnym procesem zachodzącym w większości firm świata - ich styl myślenia i działania opiera się na globalnej perspektywie, w której ujmuje się klientów, technologie, koszty, źródła finansowania, sojusze strategiczne i konkurentów. Rynek zbytu na wyroby takich firm istnieje wszędzie, gdzie są konsumenci lub odbiorcy przemysłowi, firmy te muszą przyciagać swoich klientów nie zwracając uwagi na granice państwowe, swój kraj ojczysty czy też rozmieszczenie zakładów produkcyjnych. Siłą napędową globalizacji są surowe fakty ekonomiczne - zdolność do skutecznej walki konkurencyjnej wymaga ponoszenia poważnych kosztów stałych (prace badawcze, doskonalenie technologii, sieci dystrybucji i sprzedaży, nadawanie produktom charakteru markowego), co zmusza kierownictwa firm do rozkładania tych kosztów na olbrzymie wolumeny produkcji czy sprzedaży, a to z kolei oznacza konieczność zdobywania udziałów w rynkach wszystkich ważnych gospodarczo krajów świata.

Pojęcie „globalizacja” ściśle związane jest z gospodarką globalną, czyli taką, w której czynniki produkcji: bogactwa naturalne, kapitał, technologia i siła robocza, a także produkty i usługi krążą po całym świecie. Po raz pierwszy bowiem wszystko może być wyprodukowane i sprzedane wszędzie na świecie. W gospodarce oznacza to wykonywanie każdego komponentu oraz każdej czynności w takim miejscu na kuli ziemskiej, gdzie można to zrobić najtaniej oraz sprzedawanie produktów i usług tam, gdzie ceny i zyski są najwyższe (Thurow 1999, s. 157-220). Aby pełniej zobrazować, czym jest globalizacja, warto zaprezentować, jaki był udział eksportu w produkcie światowym w ujęciu historycznym (tab. 1).

Tabela 1. Udział eksportu w produkcie światowym

\begin{tabular}{|l|l|}
\hline \multicolumn{1}{|c|}{ lata } & \multicolumn{1}{c|}{ udzial eksportu } \\
\hline 1850 & $5 \%$ \\
\hline $1913-1914$ & $12 \%$ \\
\hline okres międzywojenny, czasy II wojny światowej, kilkanaście lat po wojnie & $7 \%$ \\
\hline lata 80. i 90. & około $17 \%$ \\
\hline
\end{tabular}

Źródło: Opracowanie własne na podstawie: Kornacka 1999, s. 134 
Przedstawione w tabeli 1 dane świadczą o tym, że obecnie nie wystąpiły żadne rewolucyjne przemiany w międzynarodowych stosunkach gospodarczych. Wydaje się więc, że o istocie współczesnej globalizacji świadczyć będą nie przepływy towarów, ale przede wszystkim - co zostało już zasygnalizowane - innego rodzaju przepływy. Wszystko wskazuje na to, że największe przewartościowania dokonują się w odniesieniu do przepływu wiadomości i obrazów oraz strumieni finansowych (Kornacka 1999, s. 135).

Współcześnie bardzo trudno odróżnić zjawisko lokalne od globalnego, gdyż oba te wymiary nieustannie się przenikają i wymagają łącznego potraktowania. W wyniku nieustannego przemieszczania się ludzi tworzą się także szczególne miejsca w skali globu, mające wszędzie identyczne parametry, a nazywane „hiperprzestrzeniami”: lotniska, sieci standardowych restauracji i barów, supermarkety, sklepy muzyczne; miejsca, w których ludzie stają się osobnikami bez jakichkolwiek odniesień kulturowych.

Globalizacja jest więc faktem, a o jej istocie decyduje swoiste „kurczenie się” świata, zanikanie granic i podziałów narodowych. O istocie procesu stanowi jeszcze jedno, bardzo ważne zjawisko - nasilenie dwóch podstawowych rodzajów przepływów, tj. przepływów informacji oraz strumieni finansowych.

\section{CZYNNIKI I PRZEJAWY GLOBALIZACJI}

Globalizacja, pomimo że postrzegana jako stosunkowo nowe zjawisko, swoje początki bierze we wczesnych cywilizacjach Egipcjan, Fenicjan, Greków i Rzymian. Jej korzenie tkwią jednak w wieku XVIII, XIX i XX. To właśnie najważniejsze siły ekonomiczne, technologiczne, społeczne i polityczne spowodowały, że firmy stały się w pierwszej fazie międzynarodowe, a następnie globalne. Wszystkie te siły są powiązane wzajemnie i od siebie zależne (ryc. 1).

Technologicznych początków globalizacji należy doszukiwać się w rewolucji przemysłowej z początku XIX wieku, obejmującej wiek XIX i XX. Industrializacja stała się początkiem fabryk i masowej produkcji, co z kolei stanowiło podstawy globalizacji sektorów i koncentracji działań w pewnych obszarach. Masowa produkcja przyczyniła się również do obniżania cen i wzrostu globalnej atrakcyjności produktów. Drugą siłą, bez udziału której nie byłoby globalizacji w obecnym wymiarze, jest rozwój transportu, między innymi rozwój sieci kolei, zastosowanie silnika parowego i silnika Diesla w transporcie morskim. Wszystkie te czynniki tworzyły sprzyjający klimat do przemieszczania materiałów i wyrobów gotowych po całym świecie oraz zmniejszały bariery w podróżowaniu samym konsumentom, co umożliwiło im poznawanie nowych produktów i usług. Kolejnym elementem globalizacji jest tzw. rewolucja informacyjna. Rozwój technologii informacyjnej i komunikacyjnej ma ogromny wpływ na rozszerzanie się samej globalizacji. Komunikacja globalna (faks, Internet, poczta elektroniczna) umożliwiły firmom jednoczesną koordynację działań na całym świecie (Koźmiński, Piotrowski 1995, s. 26).

Globalizacja, jak twierdzi M. Strużycki (2000, s. 39), jest przede wszystkim, zjawiskiem o niezwykłej dynamice rozwojowej, odbieranym jako naturalny kierunek postępu w skali światowej. Nie jest to więc zjawisko wyłącznie o charakterze penetracyjnym, osłabiającym szanse wykorzystania krajowych kapitałów i lokalnych możliwości. Napływający z zewnątrz kapitał, związane z nim technologie i metody zarządzania kształtują nowy obraz 
ekonomiki kraju, wyznaczając nowe więzi o charakterze kapitałowym, marketingowym i innym. Globalizacja to proces wciąż trwający, którego rozwój w ujęciu historycznym na pewno jeszcze się nie skończył.

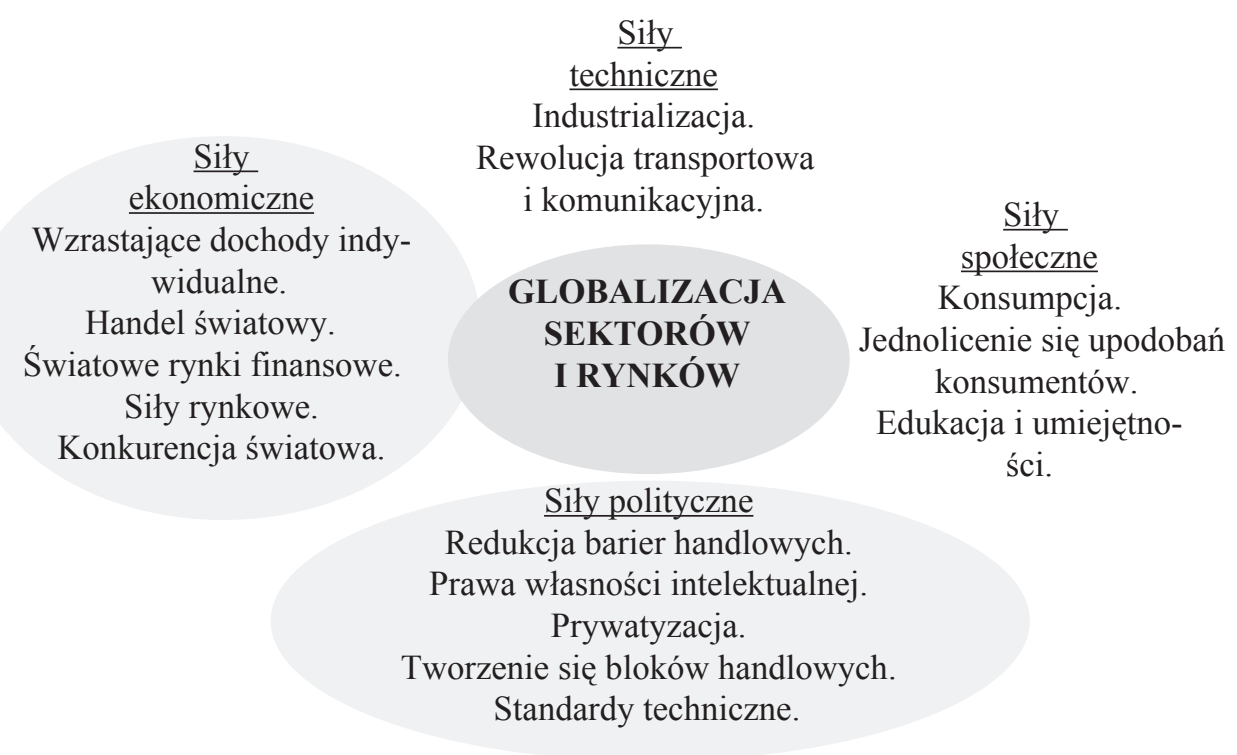

Ryc. 1. Siły prowadzące do globalizacji

Źródło: Stonehouse, Hamill, Campbell, Purdie 2001, s. 25

Analizując problemy globalizacji i historyczne kształtowanie się tego zjawiska nie sposób pominąć postaci Alvina Tofflera, który w wydanej w 1970 roku pracy Szok przyszłości pisał o rodzącym się pokoleniu koczowników, kreśląc wizje ludzi przyszłości, przenoszących się z miejsca na miejsce, których wykształcenie, wiedza i sprawność merytoryczna możliwa jest do wykorzystania, w razie potrzeby, w każdym państwie, w każdym regionie globu i na każdym kontynencie (Toffler 1995, s. 45).

W celu pełnego nakreślenia zasadniczych cech procesu niezbędne jest przypomnienie tego, co zostało określane mianem „fordyzmu”, czyli rozwinięcie się systemu masowej produkcji. Fundamentalne znaczenie miało tu zainstalowanie ruchomej linii produkcyjnej w zakładach Forda w 1913 roku, co stanowiło wówczas rozwiązanie na tyle rewolucyjne, że do lat siedemdziesiątych XX wieku był to dominujący system techniczno-ekonomiczny, zaś terminem ,fordyzm” określano wielkoseryjną produkcję i dystrybucję. W zatrudnieniu dominowali średnio i słabo wykwalifikowani pracownicy, wciąż powtarzający wyuczone czynności. System takiej produkcji, pomimo zerowej niemal elastyczności, był szeroko stosowany i - na wymogi swoich czasów - efektywny. Dążenie do coraz wyższej efektywności spowodowało przesunięcie wybranych fragmentów procesów wytwórczych do innych krajów posiadających określone zasoby taniej siły roboczej, surowców, paliw oraz inne, korzystne warunki (Zorska 1998, s. 23). Ogólna tendencja do intensyfikacji przemieszczania produkcji oraz będący jej efektem wzrost wymiany towarowej wystąpiły w sposób gwałtowny w latach osiemdziesiątych XX wieku. Powstał w ten sposób system techniczno-ekonomicz- 
ny, określany mianem ,postfordyzmu” (elastyczna specjalizacja), kształtujący się pod wpływem wielu zjawisk, wśród których najistotniejszą rolę spełniają (Zorska 1998, s. 24):

- technologie informacyjne (elektroniczne, informatyczne, komunikacyjne),

- biotechnologie,

- technologie materiałowe,

- technologie energetyczne,

- technologie kosmiczne.

Należy w tym miejscu, pomimo wielu czasami wykluczających się koncepcji, określić i usystematyzować jeszcze kilka elementów charakteryzujących współczesne procesy globalizacji. A będą to bezsprzecznie (Obłój 2002, s. 36 i in.):

- przekraczanie granic - firmy, które przekraczały granice istniały odkąd ludzie zaczęli podróżować. Obecnie jednak ludzie, produkty, pieniądze oraz informacje podróżują znacznie szybciej i taniej niż kiedykolwiek. Tańsza komunikacja, transport, przetwarzanie informacji oraz połączenia internetowe przyspieszają globalną konkurencję, a w branżach, w których zasadnicze znaczenie ma wiedza, zmniejszają bariery wejścia na obce rynki,

- budowanie przez firmy globalne trwałych relacji z dostawcami, odbiorcami, konkurentami, laboratoriami itp. Czasami relacje te przybierają postać aliansu strategicznego, a czasami istnieją „od zawsze”. Dobra relacja ceny do jakości dostaw i wieloletnia współpraca tworzą tak wysokie koszty zamiany dla obu stron, że firmy stają się od siebie zależne. W efekcie powstaje tzw. konwój, który prowadzi podążająca za swoimi klientami wielka firma międzynarodowa, zabierając ze sobą dostawców i współpracowników,

- zmiana i rozerwanie tradycyjnych powiązań - zmiana dotychczas obowiązującego, integralnego związku między procesami tworzenia dóbr materialnych, przepływami finansowymi i informacyjnymi. Pierwszy rozłam miał miejsce na linii tworzenia dóbr materialnych i obiegu finansowego. Obowiązujący na świecie system finansowy (do 1973 roku) był niezwykle prosty, gdyż wiązał wszystkie waluty z dolarem, a dolar ze złotem, w sztywnych kursach wymiennych. Złoto było więc globalne wobec lokalnych walut. Przełom nastąpił w latach sześćdziesiątych, gdy ZSRR przeniósł swoje depozyty dolarowe z USA do Wielkiej Brytanii. Innowacyjność tego posunięcia polegała na tym, że depozyt złożony w Wielkiej Brytanii pozostał nominowany w dolarach, a nie w funtach brytyjskich. W taki właśnie sposób powstał pierwszy eurodolar, czyli dolar legalnie zdeponowany poza granicami USA. Kolejnym aspektem powodującym rozerwanie omawianych powiązań był kryzys naftowy, rezygnacja z wymienialności dolara na złoto oraz tendencja krajów arabskich do trzymania swoich ogromnych depozytów w dolarach. Wszystko to, w połączeniu z dynamicznie rozwijającym się rynkiem kapitałowym, spowodowało zmodyfikowanie i uwolnienie rynku przepływów finansowych. Kolejnym rozłamem w tradycyjnej logice przedsiębiorstwa była zmiana relacji pomiędzy przepływami informacyjnymi i materialnymi. W klasycznym ujęciu przedsiębiorstwa informacja była ściśle związana z procesem transformacji zasileń w towary i usługi. Informacja w tym ujęciu stanowiła $\mathrm{z}$ jednej strony naturalne zasilanie przedsiębiorstwa (np. informacja technologiczna, marketingowa), z drugiej zaś - była naturalnym produktem (np. informacja o jakości produkcji, kosztach), nie stanowiła (lub stanowiła bardzo rzadko) samoistnego produktu. Nowoczesne techniki informacyjne, jak np. Internet, stworzyły samoistny rynek dla informacji dostępnej stosunko- 
wo tanio, powszechnie i przez cały czas. Jest to równocześnie rynek o nieskończonej liczbie dostawców i odbiorców, co pozwoliło z kolei zbudować firmy, których podstawową technologię stanowi obróbka informacji, natomiast procesy materialne mają tu charakter nieistotny lub wtórny ${ }^{1}$.

Należy podkreślić, że wraz z postępującą globalizacją rządy narodowe tracą wiele ze swoich tradycyjnych środków ekonomicznej kontroli. Skończyła się również era regulacji biznesu przez rządy państw - działalność gospodarcza bardzo często przenoszona jest tam, gdzie proces ten został ograniczony lub wyeliminowany. Osłabiona pozycja państwa narodowego bierze się z tego, że nie ma ono już możliwości ani instrumentów służących kontrolowaniu przedsiębiorstw globalnych. Przekraczając państwowe ograniczenia prawne i finansowe przedsiębiorstwa kierują się między innymi kryterium efektywności ekonomicznej w poszukiwaniu nowych miejsc działalności. Tego typu przedsiębiorstwa mają swoją ojczyznę „wszędzie i nigdzie”, ich tożsamość związana z pochodzeniem narodowym jest niezwykle luźna, co stanowi bardzo istotną cechę nowocześnie rozumianej globalizacji i jest jednocześnie wyznacznikiem działalności firm transnarodowych w XXI wieku.

\section{GlobalizacJa A UBÓstwo}

Czy globalizacja rzeczywiście generuje ubóstwo?

Pierwsza odpowiedź: nie. Entuzjaści tego procesu skłonni będą zaprzeczać występowaniu tej zależności. Wprawdzie przyznają, że w niektórych zakątkach świata następuje wzrost nędzy, ale jednocześnie nie bez racji wskazują, że właśnie dzięki globalizacji wiele ubogich regionów i krajów uzyskało szanse przezwyciężenia gospodarczego zacofania i paraliżu.

Druga odpowiedź: tak. Wydaje się, że autorzy podobnych poglądów po prostu ulegają myśleniu życzeniowemu. Niedocenianie globalizacyjnych zagrożeń jest stanowiskiem równie nierealistycznym, jak ich przecenianie. Tymczasem globalizacja jest procesem powodującym ambiwalentne skutki. Obok jednoznacznie dobroczynnych są i takie, które muszą budzić wielką troskę. Krystalizacja biegunów nieprawdopodobnego bogactwa i straszliwego ubóstwa jest jednym z nich (Dylus 2005, s. 35-45).

\section{OBLICZA ,NOWEGO UBÓSTWA”}

Wolność gospodarowania z istoty swej prowadzi do nierówności. W globalnej fazie rozwoju można wyróżnić kilka najważniejszych, wciąż nasilających się zjawisk (Dylus 2005, s. 37):

${ }^{1}$ Najsłynniejszą taką firmą - jak twierdzi K. Obłój (2002, s. 36) - jest portal internetowy Yahoo! Logika tego portalu polega na ,zbudowaniu - na rynku totalnego nadmiaru i chaosu - wielu możliwych ścieżek docierania do spokojnej i godnej zaufania przystani informacyjnej. Raz do niej zawinąwszy, można w uporządkowany sposób rozpocząć poszukiwania potrzebnej informacji w dowolnym miejscu sieci, a Yahoo! czy onet.pl ze swoją wyszukiwarką infoseek są wówczas przewodnikami i nawigatorami, którzy pozwalają z fragmentarycznych informacji umieszczonych w różnych miejscach sieci zbudować potrzebną całość”. 
1. Podczas gdy jeszcze w 1960 r. średni dochód na głowę ludności 7 najbogatszych państw był 25-krotnie wyższy niż dochód 7 państw najuboższych, to już w 1997 r. zależność ta wzrosła już 39-krotnie.

2. Różnica w dochodach między 5\% ludzi najzamożniejszych i 5\% najbiedniejszych wynosiła odpowiednio: w 1960 - 30 do 1, w 1990 - 60 do 1, zaś pod koniec XX w. - już 74 do 1 .

3. 1,7 miliarda ludzi utrzymuje się za mniej niż jednego dolara dziennie, a 4 miliardy za mniej niż dwa dolary.

4. Trzy największe fortuny świata przekraczają łączny PKB 35 najmniej rozwiniętych krajów i dochody ich 600 mln mieszkańców.

5. Dysproporcje odkrywa się także w obrębie najbogatszych państw. W USA 1\% ludności, czyli 2,7 mln osób, dysponuje zasobami równymi stanowi posiadania 38\% ludzi gorzej sytuowanych, tj. $100 \mathrm{mln}$ osób.

6. Nierówności dochodowe i majątkowe przekładają się oczywiście na stan zdrowia i długość życia - ludzie w Trzecim Świecie żyją średnio 25 lat krócej niż w krajach wysoko rozwiniętych.

Należy stwierdzić, że globalizacja, owszem, stwarza niektórym regionom i państwom szansę wyrwania się z zaklętego kręgu ubóstwa, ale dopiero po spełnieniu przez nie pewnych minimalnych warunków wstępnych. O decyzji alokacji kapitału za granicę przesądza między innymi otwarcie nowych rynków, istniejący już potencjał produkcyjny, infrastruktura, niskie koszty pracy, istnienie elementarnych instytucji społecznych (oświata, praworządność). Wiele państw zapóźnionych w rozwoju nie spełnia tych warunków, a więc nie jest w stanie zainteresować zagranicznych inwestorów, co z kolei jeszcze bardziej pogłębia dystans dzielący je od zwycięzców.

\section{EFEKTY GLOBALIZACJI W ASPEKCIE TWORZENIA SIE „NOWEGO UBÓSTWA”}

Analizę efektów globalizacji na gospodarkę światową należy rozpocząć od krajów najbogatszych, które nadawały ton światu zachodniemu. Podstawowym efektem globalizacji wydaje się być wciąż postępujący wzrost rozpiętości dochodowych między krajami zamożnymi i biednymi - różnice dochodowe per capita krajów zamożnych i najbiedniejszych od początku wieku XIX wciąż wzrastały, ale prawdziwe przyspieszenie nastąpiło w okresie ostatniego czterdziestolecia. Wiele krajów tzw. Trzeciego Świata przeżywa stagnację lub cofanie się, co nader często skutkuje fizycznym głodem. Wszystkim tym zjawiskom towarzyszy obojętność krajów zamożnych. W latach 50. i 60. uchwalono przez ONZ postulat przeznaczania 1\% PKB na pomoc dla Trzeciego Świata. Najdłużej rezolucję tę respektowały kraje nordyckie, jednak obecnie są to kwoty coraz niższe.

Wstępem do rozszerzonej analizy efektów globalizacji może być prześledzenie zmian współczynnika Giniego, wzrost którego w drugiej połowie lat 80. i w pierwszej połowie lat 90. był niezwykle szybki². W ujęciu dynamicznym współczynnik Giniego przedstawiono w tabeli 2 .

${ }^{2}$ Współczynnik Giniego jest wykorzystywany do pomiaru skali nierówności społecznej w odniesieniu do dochodu. Przyjmuje wartość 0, gdy wszyscy mają równe dochody, natomiast wartość wynoszącą 100 w sytuacjach skrajnych nierówności w podziale dochodu. 
Tabela 2. Zmiany w nierównościach dochodowych krajów najbogatszych zmiana współczynnika Giniego

\begin{tabular}{|l|c|c|l|l|l|l|l|l|l|}
\hline państwa lata & $\mathbf{1 9 8 1}$ & $\mathbf{1 9 8 3}$ & $\mathbf{1 9 8 5}$ & $\mathbf{1 9 8 7}$ & $\mathbf{1 9 8 9}$ & $\mathbf{1 9 9 1}$ & $\mathbf{1 9 9 3}$ & $\mathbf{1 9 9 5}$ & $\mathbf{1 9 9 7}$ \\
\hline Wlk. Brytania & - & - & - & 25,5 & 29,5 & 32 & 34 & 34,5 & 34 \\
Nowa Zelandia & 24 & 25 & 26 & 25,5 & 25,3 & 27 & 30 & 30 & 31,5 \\
Holandia & 28,5 & 29 & 28,5 & 28 & 29 & 31 & 32 & 32 & 32 \\
\hline USA & 40,5 & 40,5 & 40,4 & 41 & 42 & 42,2 & 42 & 42 & 42 \\
Norwegia & - & - & - & - & 22,5 & 22 & 22,5 & 23,5 & 25,5 \\
\hline Kanada & 35,5 & 35,5 & 35,5 & 36,5 & 36 & 36 & 35,5 & 36 & 36 \\
Niemcy & 24,5 & 24,5 & 24,5 & 25 & 25,1 & 25,3 & 26 & 26,2 & 27 \\
\hline Francja & 32 & 31,5 & 31 & 31 & 30,5 & 30 & 29,5 & 29 & - \\
\hline
\end{tabular}

Źródło: Opracowanie własne - dane szacunkowe na podstawie: Liberska 2002, s. 286

Należy podkreślić, że osiem najbogatszych krajów, które będą stanowiły podstawę analizy, można podzielić na cztery grupy. Do pierwszej z nich, opisaną dynamiką wzrostu współczynnika Giniego, można zaliczyć Wielką Brytanię, Nową Zelandię oraz - biorąc pod uwagę pięciolecie 1985-1990 - także Holandię. W krajach tych poziom nierówności zaczął zbliżać się do poziomu Wielkiej Brytanii.

Do drugiej grupy zakwalifikować można Stany Zjednoczone oraz Norwegię, czyli kraje z mniejszym wzrostem współczynnika Giniego, ale znaczącym i bardzo wysokim już w 1997 roku.

Trzecią grupę tworzy Kanada oraz Niemcy ze stałą wartością współczynnika Giniego. Kolejną, czwartą grupę stanowi Francja, dla której współczynnik Giniego wyraźnie spada.

Dynamiczny rozwój kilku najbogatszych krajów świata i postępujące ubóstwo państw najuboższych to kolejny efekt globalizacji, procesu, który tak naprawdę obejmuje Europę, Stany Zjednoczone i kraje Dalekiego Wschodu. Jednym z jej przejawów są rosnące dysproporcje dochodów poszczególnych, najbiedniejszych i najbogatszych krajów świata (ryc. 2).

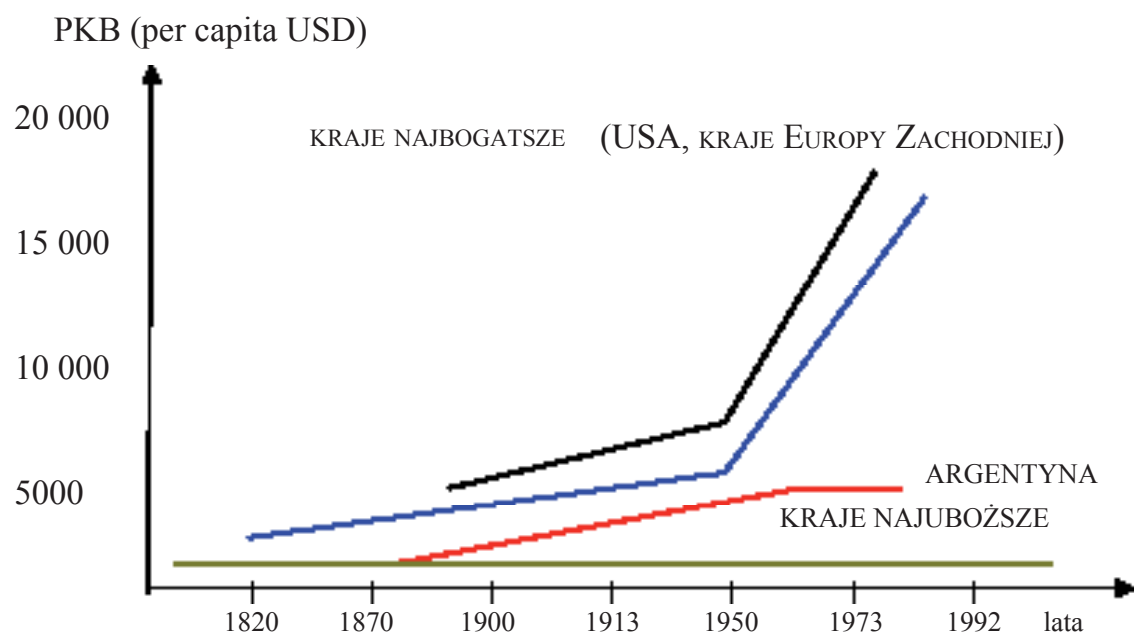

Ryc. 2. Rosnące rozpiętości dochodów 
Jednym ze sposobów zmniejszenia skali istniejących dysproporcji jest wzrost inwestycji bezpośrednich w krajach rozwijających się. Niestety, znaczenie inwestycji dla rozwoju krajów zacofanych nie znajduje pełnego potwierdzenia w faktach. Świadczą o tym dwa główne zjawiska (Kowalik 2002, s. 287):

- inwestycje omijają kraje najbiedniejsze (tylko 12 zamożniejszych wśród biednych krajów przyciaga ok. 80\% wszystkich inwestycji napływających do Trzeciego Świata),

- ogromne zadłużenie dużej części krajów Trzeciego Świata sprawia, że odpływ kapitału w postaci odsetek i rat jest większy niż przypływ pomocy oraz inwestycji zagranicznych razem.

Pokazane na ryc. 2 dane potwierdzają dynamiczny rozwój krajów najbogatszych w porównaniu z ubóstwem krajów najbiedniejszych, stanowiąc najważniejszy problem współczesnej gospodarki globalnej. Warto zauważyć, że stagnacja krajów Trzeciego Świata jest zadziwiająco stała. Oczywiste jest, że luka dochodowa między pięcioma krajami najuboższymi a pięcioma najbogatszymi istniała i powiększała się przed I wojną światową, ale tempo tego wzrostu było bardzo powolne. Przyśpieszenie nastąpiło dopiero w latach 1913-1950, natomiast ostatnie, niezwykle dynamiczne procesy związane z postępem informacyjno-komputerowym spowodowały, i na pewno będą powodować, coraz większe różnice dochodowe.

Dzisiejsze procesy globalizacji - pomimo szeregu namacalnych korzyści - wciąż wywołują szereg napięć i protestów. Adresowane są one przeciwko organizacjom postrzeganym jako siła napędowa globalizacji, którą z kolei wini się, chyba niesłusznie, za nierówności, a te z kolei są dla wielu ludzi tożsame z niesprawiedliwością, czyli nie zyskują aprobaty. Czy zatem odpowiedź na pytanie, w jakiej skali narasta nierówność i co ją powoduje nie będzie jednocześnie próbą nakreślenia efektów globalizacji? Odpowiedź wydaje się oczywista, przy czym należy zastanowić się właśnie nad przyczynami owej nierówności.

Po pierwsze, narastanie nierówności w stosunkach podziału jest faktem. O ile przez wieki ludzkość starała się z niesprawiedliwością walczyć, o tyle postęp ekonomiczny prowadził tylko do pogłębiania występujących dysproporcji.

Drugi aspekt to szczególnie uderzające narastanie nierówności podczas ostatnich dekad, szczególnie w latach osiemdziesiątych i dziewięćdziesiątych, kiedy to współczesna globalizacja oraz tzw. czwarta rewolucja techniczna nabrały wielkiego impetu. Coraz szybsze rozprzestrzenianie się kapitalistycznych stosunków produkcji na skalę globalną musi wpłynąć na zróżnicowanie dochodów. Globalizacja zwiększa obszar przedsiębiorczości, a to z kolei pociagga za sobą szybszy wzrost dochodów bardziej aktywnych grup społecznych (Kowalik 2002, s. 343).

Po trzecie, wyróżniamy wiele miar nierówności - o jaką zatem nierówność chodzi w globalnej gospodarce? Obecnie możemy wyodrębnić jej trzy wymiary (Kowalik 2002, s. 343):

- nierówność dochodowa wewnątrz kraju; narosła ona w wielu krajach i prawie wszędzie ma to związek z otwieraniem się na zewnątrz,

- nierówność pomiędzy przeciętnymi dochodami poszczególnych krajów,

- zróżnicowanie pomiędzy dochodami wszystkich mieszkańców ziemi.

Warto w tym momencie zwrócić uwagę na dość charakterystyczne zjawisko: z jednej strony w globalnym świecie usuwane są ostatnie bariery hamujące swobodny przepływ towarów i kapitałów, z drugiej natomiast poszczególne państwa tworzą nowe bariery i umac- 
niają stare, które mają uszczelnić granice państw przed migracjami ludzi najgorzej wykształconych i pozbawionych w swoich krajach perspektyw życiowych (Kowalik 2002, s. 159).

Zastanawiając się nad procesem globalizacji oraz jego efektami warto podkreślić, że to właśnie globalizacja stanowi silny czynnik przemian i jest poważnym wyzwaniem dla gospodarek, firm, instytucji, państw i całego porządku światowego. Obecnie wyróżnia się cztery główne aspekty globalizacji (Liberska 2002, s. 32):

- presja globalnych rynków finansowych (niestabilność, efekt domina),

- presja konkurencji globalnej,

- globalizacja produkcji i działalności gospodarczej (międzynarodowych sieci produkcji korporacji transnarodowych),

- infrastruktura globalizacyjna (rynki, instytucje, regulacje).

Globalizacja niesie ze sobą nowe wyzwania i wywołuje pewne efekty - jednym z nich jest powstawanie obszarów „nowego ubóstwa” we współczesnym świecie. Odpowiednich procesów dostosowawczych wymagają również różnego rodzaju instytucje przeciwdziałające ubóstwu, zarówno na szczeblu krajowym, jak i regionalnym oraz międzynarodowym. Przejawy i cechy tak rozumianej globalizacji będą długo jeszcze wyznaczać kierunek rozwoju współczesnych i przyszłych gospodarek państw i narodów.

\section{Literatura}

Dylus A., 2005, Globalizacja. Refleksje etyczne, Wrocław.

Liberska B., (red.), 2002, Globalizacja. Mechanizmy $i$ wyzwania, Warszawa.

Koch R., 1997, Stownik zarzqdzania i finansów. Narzędzia, terminy, techniki od A do Z, Kraków.

Kornacka D., 1999, Przedsiębiorstwo na rynku globalnym, [w:] S. Marek (red.), Elementy nauki o przedsiębiorstwie, Szczecin.

Kowalik T., 2002, Kapitat globalny a tendencje egalitarne i antyegalitarne, [w:] B. Liberska (red.), Globalizacja. Mechanizmy i wyzwania, Warszawa.

Koźmiński A.K., Piotrowski W., 1995, Zarzqdzanie. Teoria i praktyka, Warszawa.

Obłój K., 2002, Tworzywo skutecznych strategii, Warszawa.

Stonehouse G., Hamill J., Campbell D., Purdie T., 2001, Globalizacja. Strategie i zarządzanie, Warszawa.

Thurow L.C., 1999, Przyszłość kapitalizmu, Wrocław.

Toffler A., 1999, Szok przyszłości, Warszawa.

Strużycki M., (red.) 2000, Zarzadzanie przedsiębiorstwem, Warszawa.

Zorska A., 1998, Ku globalizacji. Przemiany w korporacjach transnarodowych $i$ w gospodarce światowej, Warszawa.

\section{Poverty forming as a result of contemporary globalization processes}

The article concerns the problems of poverty in the contemporary world and tries to present the issue against the background of globalization processes.

Apart from showing the symptoms of globalization, the author draws attention to the cause-andeffect relations between globalization and poverty. These problems are discussed more extensively, and an attempt is made to show various aspects of contemporary poverty as well as to indicate the most important features of this phenomenon. 